\title{
Technological Innovations and the Changing Character of Warfare: the Significance of the 1949 Geneva Conventions Seventy Years On
}

\section{Ozlem Ulgen*}

Seventy years after the adoption of the four Geneva Conventions on 12 August 1949 the changing character of warfare is influenced by, among other things, technological innovations such as artificial intelligence and robotics. States are integrating new technologies into the military sphere for both defensive and offensive capabilities. This impacts on military doctrines, weaponry, and operational strategies. Under the auspices of the 1980 UN Convention on Prohibitions or Restrictions on the Use of Certain Conventional Weapons Which may be Deemed to be Excessively Injurious or to have Indiscriminate Effects, the UN Group of Governmental Experts on Lethal Autonomous Weapons Systems is currently deliberating on the legal and ethical issues regarding autonomous weapons, and whether new legally binding or non-legally binding rules should be established regarding their use, restriction, or prohibition. ${ }^{1}$ In this context, it is worth reviewing the role and significance of Geneva law provisions in relation to technological innovations in methods and means of warfare.

\section{Technological innovations and impact on warfare}

Throughout history technological developments in weaponry have influenced military strategy, tactics, logistics, the outcome of war, and contributed to creating greater distance between combatants and the theatre of operation. ${ }^{2}$ Wider societal and economic developments have also impacted on how war is fought (e.g. use of railroads and steam from 1840 to 1890; steel, engineering, and electricity from 1890 to 1930; and automobile, fossil fuel, and aviation from 1930

\footnotetext{
* Reader in International Law and Ethics, School of Law, Birmingham City University, UK.

${ }^{1}$ Report of the 2018 session of the Group of Governmental Experts on Emerging Technologies in the Area of Lethal Autonomous Weapons Systems, 23 October 2018, CCW/GGE.1/2018/3.

${ }^{2}$ E.g. the crossbow in China 475 BC; the dagger-axe blade in the Qin Dynasty 221-206 BC, China; gunpowder in the Tang Dynasty 618-907, China; the V-2 Rocket in 1944; the atom bomb in 1945; and today's unmanned armed aerial vehicles such as the MQ-9 Reaper. See generally, Tonio Andrade, The Gunpowder Age: China, Military innovation, and the Rise of the West in World History (Princeton University Press 2016); Martin van Creveld, Technology and War: From 2000 B.C. to the Present (The Free Press 1991).
} 
to 1990). ${ }^{3}$ The ever-growing, fast-paced nature of information and communication technologies, coupled with the rise of artificial intelligence and autonomous robotics, is the "fourth revolution" to impact on warfare. Nanotechnology, biotechnology, robotics, information and communication technology, and applied cognitive science are the "Five Horsemen" impacting on twenty-first century warfare. ${ }^{4}$ We can see the impact through the introduction of new methods and means of warfare (e.g. lethal autonomous robots; pharma enhanced warriors; cyberspace weapons; miniature surveillance devices). The deployment of such technologies cuts across different types of conflicts including asymmetric warfare, military police operations, transboundary and diffuse conflicts, including state and non-state actors. What has been referred to as the "Five Horsemen" emerging technologies have the potential to destabilise existing military cultures and institutions with privatisation of military activities and institutions, and the propensity towards information dense warfare reliant on complex algorithms. The civilian sphere is also impacted particularly through development and use of dual-use technologies, privatisation of government activities, human enhancement technology in civil society, new weapons in civil society, and general militarisation of society. 5

\footnotetext{
${ }^{3}$ Nathan Rosenberg and L.E. Birdzell Jr., How the West Grew Rich: The Economic Transformation of the Industrial World (Basic Books 1986); Chris Freeman and Francisco Louçã, As Time Goes By: From the Industrial Revolutions to the Information Revolution (OUP 2001); Max Boot, War Made New (Gotham Books 2006).

${ }^{4}$ Braden R. Allenby and Daniel Sarewitz, The Techno-Human Condition (MIT Press 2011); Brad Allenby, 'The Implications of Emerging Technologies for Just War Theory’ (2013) 27(1) Public Affairs Quarterly pp. 49-67.

5 Miles Brundage et. al., 'The Malicious Use of Artificial Intelligence: Forecasting, Prevention, and Mitigation' (Future of Humanity Institute, Report February 2018); Peter Asaro, "Will \#BlackLivesMatter to RoboCop?” WeRobot 2016 , University of Miami School of Law, Miami, FL, 1-2 April 2016; Peter Asaro, “"Hands Up, Don't Shoot!" HRI and the Automation of Police Use of Force' Special Issue on Robotics Law and Policy, Journal of Human-Robot Interaction (2016) 5(3) pp. 55-69.
} 
States are integrating artificial intelligence and robotics into the military sphere for both defensive and offensive capabilities. ${ }^{6}$ For example, although there is no international definition of lethal autonomous weapons systems (LAWS), such weapons systems are characterised by use of artificial intelligence and robotics in order to achieve varying degrees of autonomy in the critical functions of acquiring, tracking, selecting, and attacking targets; and, to some extent or even fully, remove human involvement from the decision-making process to use lethal force. ${ }^{7}$ LAWS impact on the interpretation and application of international humanitarian law (IHL) principles of distinction, proportionality, precautionary measures, as well as attribution of responsibility for general and grave breaches. ${ }^{8}$ Removal of human cognitive abilities (such as exercising judgment, reasoning, and discretion in a war context) and replacing them with machines in order to execute an attack and cause death, injury, and damage raises fundamental legal and ethical issues about potential lack of human agency, control, and responsibility.

\subsection{Maintaining human agency}

Over-reliance on weapons technology innovations that remove combatants from the theatre of operation and abdicate human cognitive abilities to machines, challenge the fundamental feature of IHL that its interpretation and application is predicated on individuals, as demonstrated by concepts

\footnotetext{
${ }^{6}$ Air defence systems with autonomous engagement (e.g. NBS Mantis (Germany), Phalanx (USA), SeaRAM (Germany, USA)); active protective systems with autonomous engagement (e.g. Iron Curtain (USA), Iron Fist (Israel); the US Navy X-47B autonomous jet developed as a surveillance, strike, and reconnaissance system; C-RAM, counter rocket, artillery, and mortar round defensive system, used in Iraq in 2004/5 in response to insurgent rockets and artillery, although highly automated has capacity for other uses; Guardium, Israeli unmanned ground vehicle; Crusher, American unmanned ground combat vehicle; Anjian (Dark Sword), Chinese jet-powered unmanned combat aerial vehicle; Mikoyan Skat, Russian stealth unmanned combat aerial vehicle; Dassault nEUROn, unmanned combat aerial vehicle project (France, Greece, Italy, Spain, Sweden and Switzerland); AURA, autonomous stealth bomber project (India); French position that artificial intelligence could be used in military applications to assist decision-making and targeting (Exchange of views of France (13 November 2017), UN Digital Recordings Portal, at $<$ http://conf.unog.ch/digitalrecordings/\#>); Russian position that improving autonomy levels in weapons systems such as precision-guided missiles can achieve accuracy in targeting of military assets (Russian paper, Russia's Approaches to the Elaboration of a Working Definition and Basic Functions of Lethal Autonomous Weapons Systems in the Context of the Purposes and Objectives of the Convention, CCW/GGE.1/2018/WP.6, 4 April 2018, para. 9); Dutch position that autonomous weapons systems can operate in environments that are dangerous or difficult for humans (The Netherlands paper, Examination of various dimensions of emerging technologies in the area of lethal autonomous weapons systems, in the context of the objectives and purposes of the Convention, CCW/GGE.1/2017/WP.2, 9 October 2017, para. 12); UK funding of artificial intelligence research programmes with military applications (Peter Burt, 'Off the Leash: The development of autonomous military drones in the UK' (Drone Wars UK, Report November 2018)).
}

${ }^{7}$ Ozlem Ulgen, 'Human Dignity in an Age of Autonomous Weapons: Are We in Danger of Losing an 'Elementary Consideration of Humanity'?' (2018) 17/18 Baltic Yearbook of International Law (forthcoming); Ozlem Ulgen, 'Definition and Regulation of LAWS' (UN GGE LAWS Report, 5 April 2018) 1-24 at: https://www.unog.ch/

80256ee600585943.nsf/(httpPages)/7c335e71dfcb29d1c1258243003e8724?

OpenDocument\&ExpandSection=6\# Section6.

${ }^{8}$ Ulgen, 'Definition and Regulation of LAWS', $i d$. 
such as individual criminal responsibility, and command responsibility. ${ }^{9}$ This extends to the specialised area of weapons law, including human involvement in the design, development, and employment of new weapons technologies. Several IHL provisions reflect the need for human agency.

Article 1(1) of the 1907 Hague Convention IV Regulations provides that laws, rights, and duties are not only applicable to armies but also to militia and volunteer corps that are "commanded by a person responsible for his subordinates". Article 26 of the Regulations requires that "the officer in command of an attacking force must, before commencing a bombardment, except in cases of assault, do all in his power to warn the authorities." Article 45 of the 1949 Geneva Convention I (Wounded and Sick on Land) and Article 46 of the 1949 Geneva Convention II (Wounded, Sick and Shipwrecked at Sea) contain a common provision relating to the execution of obligations which requires "each party to the conflict, acting through its Commanders-in-Chief [to] ensure the detailed execution of the preceding Articles, and provide for unforeseen cases, in conformity with the general principles of the present Convention." Article 87(1) of Additional Protocol I (API) requires "military commanders, with respect to members of the armed forces under their command and other persons under their control, to prevent and, where necessary, to suppress and to report to competent authorities breaches of the Conventions and of this Protocol." Article 87(2) requires commanders to "ensure that members of the armed forces under their command are aware of their obligations under the Convention and this Protocol." Article 87(3) requires "any commander who is aware that subordinates or other persons under his control are going to commit or have committed a breach of the Conventions or of this Protocol, to initiate such steps as are necessary to prevent such violations of the Conventions or this Protocol, and, where appropriate, to initiate disciplinary or penal action against violations thereof."

At the UN Group of Governmental Experts on Lethal Autonomous Weapons Systems (GGE) there was general state consensus that the human agency aspect of IHL must be maintained in relation to LAWS. ${ }^{10}$ States are concerned to maintain human control over lethal targeting functions, and for

\footnotetext{
${ }^{9}$ See for example, Art. 7 of the 1993 ICTY Statute; Art. 6 of the 1994 ICTR Statute; Arts. 25 and 28 of the 1998 Rome Statute of the ICC; Art. 15 of the 1999 Second Hague Protocol on the Protection of Cultural Property in the Event of Armed Conflict.

${ }^{10}$ Report of the 2017 Group of Governmental Experts on Lethal Autonomous Weapons Systems (LAWS), CCW/GGE. 1/2017/CRP.1, para. 16(c) ('GGE Report 2017’).
} 
machines not to replace humans in making decisions and judgments. ${ }^{11}$ Concepts such as "meaningful human control", 12 "human control", 13 "human judgment", 14 "human involvement", 15 and "human supervision"16 have been variously invoked and used interchangeably to capture the essence of human agency. Human agency in decision-making, conduct of hostilities, choice of weapons, and the weapons lifecycle is apparent in several IHL provisions. Methods and means of attack which the commander decides to employ come under command responsibility under Article 57(2)(a)(ii) API. If the commander orders employment of a weapon in the knowledge that it cannot predictably and reliably discriminate between combatants and civilians, or military objectives and civilian objects, this would be a failure to discharge the duty to prevent and suppress breaches of IHL under Article 87(1) API. Prior to an attack, under Article 57 API there is an obligation to take feasible precautions to reduce the risk to civilians and civilian objects. This obligation is carried out by "those who plan or decide an attack", meaning commanders/superiors. They must verify that the targets of attack are military objectives and not civilians or civilian objects. They must take feasible precautions in the choice of means and methods of attack in order to avoid or minimise civilian loss, injury, or damage. They must refrain from attacking if it is expected to cause excessive civilian loss, injury, or damage.

\footnotetext{
${ }^{11}$ GGE Report 2017, id., Annex II, Chair’s summary of the discussions, para. 4.

12 Exchange of views of Pakistan, Switzerland, New Zealand, Korea (13 November 2017); Finland, Ireland, Russia, Turkey (15 November 2017); the Netherlands, Sierre Leone (16 November 2017), UN Digital Recordings Portal, at $<\underline{\text { http://conf.unog.ch/digitalrecordings/\#> }}$. See also, Article 36 NGO Briefing Paper (2016), Briefing paper for delegates at the Convention on Certain Conventional Weapons (CCW) Meeting of Experts on Lethal Autonomous Weapons Systems (LAWS) on Meaningful Human Control, Artificial Intelligence and Autonomous Weapons (11-15 April 2016); PAX NGO Report (2017), Keeping Control: European positions on lethal autonomous weapons (October 2017), p. 23.

13 Exchange of views of the EU, Kazakhstan, Brazil, Germany (13 November 2017); China, ICRC expert panel (14 November 2017); Croatia, UK, Peru, Pakistan, Argentina, (15 November 2017); the NAM, Poland, Italy, Switzerland, Japan, Estonia, Austria (16 November 2017), UN Digital Recordings Portal, at $<\underline{\text { http://conf.unog.ch/digitalrecordings/ }}$ \#>. See also, ICRC Statement (2017), Convention on Certain Conventional Weapons (CCW) Group of Governmental Experts on Lethal Autonomous Weapon Systems (13-17 November 2017, Geneva).
}

14 Exchange of views of Zambia, Norway (15 November 2017); the Netherlands, Estonia, Ireland (16 November 2017), UN Digital Recordings Portal, at $<$ http://conf.unog.ch/digitalrecordings/\#>. See also, USA paper (2017a), Autonomy in Weapon Systems, CCW/GGE.1/2017/WP.6; Government of Israel Statement (2016), Statement on Lethal Autonomous Weapons Systems (LAWS): Weapon Legal Review (11-15 April 2016).

${ }^{15}$ Exchange of views of ICRC expert panel (14 November 2017); China (15 November 2017); Chair, Austria (16 November 2017), UN Digital Recordings Portal, at $<\underline{\text { http://conf.unog.ch/digitalrecordings/\#>. }}$

${ }^{16}$ Exchange of views of the USA (16 November 2017), UN Digital Recordings Portal, at $<$ http://conf.unog.ch/digitalrecordings/\#>; Belgian paper (2017), Towards a definition of lethal autonomous weapons systems, CCW/GGE.1/2017/ WP.3; ICRC Statement (2017), Convention on Certain Conventional Weapons (CCW) Group of Governmental Experts on Lethal Autonomous Weapon Systems (13-17 November 2017, Geneva). 
In the targeting process, Article 48 API requires parties to the conflict to distinguish between the civilian population and combatants and between civilian objects and military objectives. Although the term "parties" may imply that states can discharge this obligation by using advanced target recognition systems, in practice this would be difficult to maintain in dynamic environments, mixed civilian-military areas, and in identifying civilians with ambiguous status. Human involvement in the targeting process, which may be assisted by target recognition technology, is needed to maintain situational awareness, the ability to observe and interpret human behaviour, and the ability to qualitatively assess different variables. Article 50(1) API requires that any ambiguity about the civilian status of an individual shall be resolved in their favour, emphasising the importance of human assessment, appraisal, and exercise of discretion. ${ }^{17}$ The same presumption applies to ambiguous civilian objects under Article 52(3) API. Human agency is also required under Articles 51(5)(b) and 57 API in the exercise of judgment prior to attack to make a proportionality assessment; that is, whether the anticipated military advantage to be gained from attacking is proportionate to the expected incidental civilian injury, including death to civilians and damage to civilian objects.

Whatever terminology is used, the type and extent of human control will be crucial to ensuring human agency exists. A simple human operated on/off switch that triggers an attack does not demonstrate adequate human control by way of exercising judgment, reasoning, and discretion. Human control would need to include actual and effective exercise of judgment and reasoning within the pre-deployment and deployment stages. In the pre-deployment stage, numerous human agents are involved in discharging the weapons review obligation under Article 36 API, which requires that in the study, development, acquisition or adoption of a new weapon, means or method of warfare, is must be determined that the weapon is compliant with IHL and international law generally. Civilian superiors, legal advisers, designers, programmers, engineers, manufacturers, private contractors, and private military firms would exercise judgment and reasoning for decisions to undertake new weapons research, and to design and develop new or modified weapons systems that comply with IHL. ${ }^{18}$ In the deployment stage, as noted above, Articles 48, 50, 51, 52, and 57 API would require

\footnotetext{
${ }^{17}$ See for example, Prosecutor v Blaškić, (ICTY Appeals Chamber) 29 July 2004, para. 111, where the ICTY Appeals Chamber noted that "the imperative 'in case of doubt' is limited to the expected conduct of a member of the military", and that human involvement is important for establishing criminal responsibility.

18 Ozlem Ulgen, 'Pre-deployment common law duty of care and Article 36 obligations in relation to autonomous weapons: interface between domestic law and international humanitarian law?' (2016/17) 55(1) The Military Law and the Law of War Review pp. 1-29.
} 
exercise of human judgment, reasoning, and discretion for choice of weapons, feasible precautions, and implementation of the principles of distinction and proportionality.

Command responsibility is an example of human agency relevant to LAWS and any new weapons technologies. ${ }^{19}$ As part of customary international law and treaty law, it attaches criminal responsibility to military commanders and civilian superiors for specific failures in duties. ${ }^{20}$ Commanders are qualified to exercise control over their troops and the weapons they use in order to ensure that persons and objects afforded protection under IHL are in fact protected. ${ }^{21}$ Although commanders may not pull the trigger, fire the missile, or drop the ordnance, they are direct participants in the hostilities in that they decide on the attack, means of attack, and give orders. ${ }^{22}$ Their duties include properly supervising and controlling subordinates, and ensuring they do not commit war crimes. If they commanders fail to take necessary and reasonable measures to prevent or punish a subordinate's crimes, which they knew or had reason to know were about to be committed or being committed, they may be held criminally liable. ${ }^{23}$

\subsection{Limitless range of methods and means}

The dual-use nature of emerging technologies may precipitate a blurring of domestic law enforcement techniques with military operations to the detriment of IHL principles. The rules of engagement for American UAV operations in Pakistan and Afghanistan have allowed strikes on armed men of military age deemed to be engaged in or associated with suspicious activity, even if their identities are not known. These behavioural requirements are normally found in domestic law enforcement but by using them in military operations the targeting threshold is lowered to include even be-

\footnotetext{
19 Ozlem Ulgen, 'Command Responsibility and LAWS' (UN GGE LAWS Report, 22 August 2018) 1-10 at: https:// www.unog.ch/_80256ee600585943.nsf/(httpPages)/7c335e71dfcb29d1c1258243003e8724?OpenDocument\&ExpandSection=6\#_Section6.

${ }^{20}$ R. John Pritchard and Sonia Magbanua Zaide (eds), The Tokyo War Crimes Trial, Vol. 20 (Garland Publishing 1981) 49, 816; United States v. Friedrich Flick et al, US Military Tribunal at Nuremberg, 22 December 1947, Trials of War Criminals before the Nuremberg Military Tribunals under Control Council Law No. 10, Vol VI, 11-16; Prosecutor v. Delalić et al, IT-96-21-T (16 November 1998), paras. 355-363; Article 86(2) API; Article 7(3) ICTY Statute; Article 6(3) ICTR Statute; Article 28(a) and (b) ICC Statute.

${ }^{21}$ Yves Sandoz, Christophe Swinarski and Bruno Zimmermann (eds), ICRC Commentary on the Additional Protocols of 8 June 1977 to the Geneva Conventions of 12 August 1949 (ICRC 1987) Art. 87 API para. 3560; Prosecutor v. Enver Hadžihasanović and Amir Kubura, Case No. IT-01-47-T, (Judgement, 15 March 2006), para. 89.

22 See William Boothby, The Law of Targeting (OUP 2012) 356.

${ }^{23}$ Prosecutor v. Delalić et al, IT-96-21-T (16 November 1998), paras. 343-400; Prosecutor v. Orić, IT-03-68-T (30 June 2006), paras. 289-338; Arts. 86 and 87 API; Art. 7(3) ICTY Statute; Art. 6(3) ICTR Statute; Art. 28 ICC Statute.
} 
ing "associated with suspicious activity", thus increasing the number of targets. This undermines principles of distinction, taking feasible precautions, and capture without killing where possible. ${ }^{24}$ China's use of facial recognition technology and the integrated joint operations platform (Ijop), a regional data system that uses artificial intelligence to monitor checkpoints, as part of a mass surveillance counter-terrorism operation in the Xinjiang region, has come under much criticism. ${ }^{25}$

Modern warfare has been characterised as the prevalence of low-intensity conflicts with a limitless range of violence that may blur the distinction between combatants and civilians, and strive for legitimacy to win the "hearts and minds" of people. ${ }^{26}$ This also captures situations where a state may use new technologies in the territory of another state without believing it is engaging in armed conflict or declaring a state of war. New concepts are emerging with potential to blur the distinction between civilian and military use of technologies. "Battlespace" refers to the integrated information management of all factors impacting combat operations relating to air, land, sea, space, and cyber. ${ }^{27}$ China aims to leverage AI to create systems for intelligent monitoring, and early warning and control of potential threats. It refers to the “military-civilian fusion” doctrine (jūnmín rónghé 军民融 合) whereby resources and advances are shared and transferred between civilian and military contexts through normalising mechanisms for communication and coordination among scientific research institutions, universities, enterprises and military industry; and "intelligentized warfare” (zhìnéng huà zhàn 智能化战) whereby exploitation of new generation AI is a "powerful support" to command decision-making and defence equipment. ${ }^{28}$ These seem to be a continuation of the "beyond-limits warfare" doctrine of the 1990s which advocated avoiding focusing on one

\footnotetext{
24 See critique of domestic law enforcement model and international humanitarian law model used in American targeted killings in Michael Newton and Larry May, Proportionality in International Law (OUP 2014), chapter 10.

${ }^{25}$ See Joint Statement to the UN High Commissioner for Human Rights by 22 States (8 July 2019); Human Rights Watch Report, “"Eradicating Ideological Viruses”: China's Campaign of Repression Against Xinjiang's Muslims' (9 September 2018); Darren Byler, 'China’s hi-tech war on its Muslim minority’, The Guardian, 11 April 2019.

${ }^{26}$ Charles Townshend (ed), The Oxford History of Modern War (OUP 2000) p. 19.

27 Dave Wallace and Shane Reeves, 'Non-State Armed Groups and Technology: the Humanitarian Tragedy at Our Doorstep?' (2013) 3 Miami Nat'l Security \& Armed Conflict L. Rev. 26-45, who refer to "non-state armed groups" practising "asymmetric warfare" involving "leveraging inferior tactical or operational strength against the vulnerabilities of a superior opponent [i.e. the State] to achieve disproportionate effect with the aim of undermining the opponent's will in order to achieve the asymmetric actor's strategic objective" p. 27.
}

${ }^{28}$ New Generation Artificial Intelligence Development Plan (AIDP) (20 July 2017). 
particular technology, approach or weaponry to warfare, and instead adopting a combined and defused model that enabled all and any response across domains in order to meet limited objectives. ${ }^{29}$

The "beyond-limits warfare" 30 military doctrine reflects the limitless range of methods and means. It aims to counter the effect of an attack from militarily and technologically advanced states in a high-tech war. ${ }^{31}$ It makes no distinction between what is and what is not a battlefield, and includes the seas, the air, outer space, and social spaces such as the military, politics, economics, culture, and the psyche. ${ }^{32}$ Key to this doctrine is the acceptance of unlimited methods and means, including new weapons technology, in order to achieve military objectives. This is contrary to the customary law principle, as contained in Article 35(1) API, that states do not have the right to limitless methods and means of warfare. But the "beyond-limits warfare" doctrine may be tempered by other factors. One factor is that a military objective must be limited so that appropriate methods and means are chosen. Another factor is that in order to accomplish some designated objective, unlimited methods and means may involve overcoming restrictions and choosing a variety of measures, to the exclusion of atomic weapons, which due to their potential to annihilate mankind cannot serve a designated and limited military objective. In Legality of the Threat or Use of Nuclear Weapons, although the ICJ could not definitively conclude whether nuclear weapons would be lawful or unlawful in an extreme circumstance of self-defence involving state survival, the majority opined that the threat or use of nuclear weapons would "generally be contrary to the rules of international law applicable in armed conflict, and in particular the principles and rules of humanitarian law".33

It has also been argued that a limitless range of methods and means is a potentially constraining feature of modern warfare. ${ }^{34}$ No single weapon will dominate the military sphere for "the more weapons [that] are invented, the smaller an individual weapon's role in war becomes, and this is the

\footnotetext{
ing Military and Security Technologies (Ashgate 2015) pp. 87-98.

${ }^{30} \mathrm{Id}$

${ }^{31} I d$.

${ }^{32} I d$.

${ }^{33}$ Legality of the Threat or Use of Nuclear Weapons [1996] ICJ Rep 226, p. 266 para. 105.

${ }^{34}$ Qiao Liang and Wang Xiangsui, supra note 29, p. 66.
}

29 Qiao Liang and Wang Xiangsui, 'Unrestricted Warfare' in Braden R. Allenby Braden, The Applied Ethics of Emerg- 
paradox that is inherent in the relationship between weapons and war." 35 Terms such as "hi-tech warfare", "information warfare", "cyber warfare" sensationalise the dominance of technology, irrespective of the type of conflict, as if to remove all human agency.

\section{Geneva law on new weapons}

IHL is generally applicable to new weapons technologies in two key respects. First, the law restricts or prohibits certain types of weapons which by their nature cause superfluous injury or unnecessary suffering, ${ }^{36}$ or which are indiscriminate because they cannot be directed at a specific military objective, or because their effects cannot be limited as required by IHL. ${ }^{37}$ Second, if the weapon is not prohibited, the law governs its use through principles of distinction, proportionality, and precautions. ${ }^{38}$ Examples of restricted or prohibited weapons include mines and booby-traps, ${ }^{39}$ anti-personnel mines; ${ }^{40}$ poison and poisoned weapons; ${ }^{41}$ chemical weapons ${ }^{42}$; and prohibition of blinding laser weapons that cause permanent blindness. ${ }^{43}$ Depending on the nature and effect of a new weapon, it may be classified as a prohibited weapon. ${ }^{44}$ If it cannot be directed at a specific military objective, or causes superfluous injury or unnecessary suffering, or its effects cannot be limited as required by IHL, then it would be considered indiscriminate and prohibited. ${ }^{45}$ The $u s e$ aspect of the law clearly engages human agency and will require human control to verify targets, assess and limit the effects of an attack, and abort a mission.

${ }^{35} \mathrm{Id}$.

${ }^{36}$ Art. 35(2), 1977 API (emphasis added).

${ }^{37}$ Art. 51(4)(b) and (c), 1977 API.

${ }^{38}$ Arts. 48, 51(5)(b), 57(1), 57(2)(a)(ii) and (iii), 57(2)(b), 58, 1977 API. These principles are part of customary international law, Legality of the Threat or Use of Nuclear Weapons [1996] ICJ Rep [78]-[79]; Prosecutor v. Kupreškić et al, ICTY Trial Chamber, IT-95-16-T (14 January 2000) para. 524 (emphasis added).

${ }^{39}$ Arts. 3, 4 and 6, 1996 Amended Protocol II to the Convention on Certain Conventional Weapons.

40 Art. 1, 1997 Ottawa Convention on the Prohibition of the Use, Stockpiling, Production and Transfer of AntiPersonnel Mines and on Their Destruction.

${ }^{41}$ Art. 70, 1863 Lieber Code; Art. 23(a), 1907 Hague Convention IV Regulations.

421899 Hague Declaration concerning Asphyxiating Gases; 1925 Geneva Protocol for the Prohibition of the Use in War of Asphyxiating, Poisonous or Other Gases, and of Bacteriological Methods of Warfare; Art. 1, 1993 Convention on the Prohibition of the Development, Production, Stockpiling and Use of Chemical Weapons and on their Destruction.

${ }^{43}$ Art. 1, 1995 Amended Protocol IV to the Convention on Certain Conventional Weapons.

${ }^{44}$ Arts. 35(2), 51(4)(b) and (c) API.

${ }^{45} \mathrm{Id}$. 
Aside from the nature and use questions of new weapons, the Martens Clause and the obligation to undertake weapons reviews demonstrate the continued relevance of Geneva law even in times of uncertainty and change.

\subsection{The Martens Clause - anchoring technology to the interests of humanity?}

The Martens Clause is a fundamental feature of the Geneva Conventions. It was initially contained in the preamble to the 1899 Hague Convention II on the Laws and Customs of War on Land, and the preamble to the 1907 Hague Convention IV on the Laws and Customs of War on Land. It was subsequently reaffirmed in Article 63 paragraph 4 of 1949 Geneva Convention I; Article 62 paragraph 4 of 1949 Geneva Convention II; Article 142 paragraph 4 of 1949 Geneva Convention III; Article 158 paragraph 4 of 1949 Geneva Convention IV; Article 1(2) of Additional Protocol I of 1977 to the Geneva Conventions, and the preamble to Additional Protocol II; and the preambular paragraph 5 of the 1980 UN Convention on Certain Conventional Weapons. ${ }^{46}$ Today, it is best reflected in Article 1(2) of Additional Protocol I of 1977:

\footnotetext{
"In cases not covered by the present Protocol or other international agreements, civilian persons and combatants remain under the protection and authority of the principles of international law, proceeding from established customs, the principles of humanity and the dictates of the public conscience."
}

This all-encompassing blanket provision reminds us of IHL's concern for protection and responsibility of humans. The 1899 Hague Conference deliberately set broad terms of "principles of humanity" and "the dictates of the public conscience" to cover scenarios not addressed under positive law and where consensus between negotiating parties could not be reached. ${ }^{47}$ It was intended to settle a disagreement between smaller states and the Great Powers regarding the status of resistance movements in occupied territories. ${ }^{48}$ Smaller states favoured protection of inhabitants of occupied territories who took up arms against occupying forces as lawful combatants. But they failed to obtain a

\footnotetext{
${ }^{46}$ For commentary on these provisions see, Dieter Fleck (ed), The Handbook of Humanitarian Law in Armed Conflict (OUP 2008) pp. 33-35.

47 The Proceedings of The Hague Peace Conferences Translation of the Official Texts - Conference of 1899 (J B Scott ed, 1920), Sixth Meeting, 6 June 1899, p. 500ff; Eleventh Meeting, 20 June 1899, p. 548ff.

${ }^{48} \mathrm{Id}$.
} 
majority for combatant status of these persons to be recognised in Article 2 of the Hague Regulations. ${ }^{49}$ So the Martens Clause filled the gap by allowing interpretation of their protection on a caseby-case basis. It has since attained a pervasive nature in both custom and treaty law aimed at reflecting the interests of humanity, controlling military conduct, ${ }^{50}$ and placing humans at the centre of IHL's remit. ${ }^{51}$ Thus, a new weapon, even if not yet employed, regulated, or prohibited, would still have to be assessed against the interests of humanity regarding its nature and effects. ${ }^{52}$ The Clause, as reflected in the Geneva Conventions, also serves as an enforcement mechanism by ensuring that even if parties to a conflict have denounced treaty law, they remain bound by pre-existing customs of warfare limiting harmful effects.

In Legality of the Threat or Use of Nuclear Weapons the ICJ specifically identified the Martens Clause, as contained in Article 1(2) API, as of fundamental importance and "an effective means of addressing rapid evolution of military technology". ${ }^{53}$ During the CCW Fifth Review Conference and at subsequent meetings of the GGE, several states referred to the Martens Clause as relevant and important to discussions on LAWS. ${ }^{54}$ Although the 2017 Franco-German proposal, supporting a political declaration leading to a code of conduct on LAWS, does not specifically refer to the Martens Clause, the reference to "rules of international law, in particular international humanitarian law, are fully applicable to the development and use of LAWS" would include it. ${ }^{55}$

\subsection{Article 36 API weapons reviews}

${ }^{49} I d$.

${ }^{50}$ See, Legality of the Threat or Use of Nuclear Weapons, Advisory Opinion of 8 July 1996, ICJ Reports 1996, Dissenting Opinion of Judge Shahabudden, pp. 405-411.

${ }^{51}$ See, Robert Kolb, 'The main epochs of modern international humanitarian law since 1864 and their related dominant legal constructions' in Kjetil Mujezinović Larsen, Camilla Guldahl Cooper and Gro Nystuen (eds), Searching for a 'Principle of Humanity' in International Humanitarian Law (CUP 2013); Theodor Meron, 'The Humanisation of Humanitarian Law' (2000) 94 Am. J. Int'l L. p. 239.

52 Yves Sandoz, Christophe Swinarski and Bruno Zimmermann (eds), ICRC Commentary on the Additional Protocols of 8 June 1977 to the Geneva Conventions of 12 August 1949 (ICRC 1987), paras. 55-56.

${ }^{53}$ Legality of the Threat or Use of Nuclear Weapons, Advisory Opinion of 8 July 1996, ICJ Reports 1996, 226, p. 257 para. 78.

${ }^{54}$ CCW 5th Review Conference of the High Contracting Parties, Exchange of Views: Ecuador, Panama (12 December 2016); Costa Rica, Guatemala, (13 December 2016), UN Digital Recordings Portal, at $<$ http://conf.unog.ch/digitalrecordings/\#>. See views of Sri Lanka, Costa Rica, Greece, Brazil, and Sierre Leone (13 November 2017), UN Digital Recordings Portal, at $<$ http://conf.unog.ch/digitalrecordings/\#>.

55 Franco-German paper (2017), For consideration by the Group of Governmental Experts on Lethal Autonomous Weapons Systems (LAWS), CCW/GGE.1/2017/WP.4, para. 12(b). 
Article 36 API plays a vital role in the area of new weapons and IHL's primary concern for a human agency continuum:

\begin{abstract}
"In the study, development, acquisition or adoption of a new weapon, means or method of warfare, a High Contracting Party is under an obligation to determine whether its employment would, in some or all circumstances, be prohibited by this Protocol or by any other rule of international law applicable to the High Contracting Party."
\end{abstract}

The obligation to review new weapons is expressed in terms of various stages of the weapons lifecycle (i.e. study, development, acquisition or adoption of a new weapon, means or method of warfare). The study, research and developmental stages of new weapons using new technologies is crucial, especially where dual-use technologies are involved or autonomous functions are being introduced into weapons systems which could eliminate human agency. States are particularly sensitive to prohibitions or restrictions on new technologies which may lead to beneficial civilian uses. ${ }^{56}$ But there is a clear separation between the intended purposes and uses of new technologies in the civilian sphere, and potential military uses. Technology may be used to enhance combat efficiency, widen domain areas, and diversify military operations (e.g. artificial intelligence assisting combatants in target assessments). ${ }^{57}$ So long this supplements rather than replaces human agency, it would not necessarily breach IHL rules. For any weapons system to fall within military command and control it must be capable of being monitored, supervised, and deactivated by humans. Knowing what the technology is being used for seems key to ensuring continued compliance with IHL.

Article 36 provides no definition of "weapon", "means" or "methods" of warfare, yet all three categories are subject to the weapons review process and state practice provides a common understanding of these categories. Rule 1(ff) of the 2013 HPCR Manual on International Law Applicable to Air and Missile Warfare, which restates existing international law on air and missile warfare, based on general state practice and opinio juris and treaties in force, defines "weapon" as:

\footnotetext{
${ }^{56}$ Exchange of views of Belgium, Korea, Iraq (13 November 2017); Russia, Finland (15 November 2017); Uganda (16 November 2017), UN Digital Recordings Portal, at <http://conf.unog.ch/digitalrecordings/\#>. See also EU (2017) Statement on Lethal Autonomous Weapons Systems (LAWS) Group of Governmental Experts Convention on Certain Conventional Weapons, Geneva, 13-17 November 2017.

57 See views of Professor Heigo Sato, Takushoku University (14 November 2017), UN Digital Recordings, at $<\underline{\text { http:// }}$ conf.unog.ch/digitalrecordings/\#>, and Dr David Shim, KAIST Institute of Robotics (14 November 2017).
} 
"a means of warfare used in combat operations, including a gun, missile, bomb or other munitions, that is capable of causing either (i) injury to, or death of, persons; or (ii) damage to, or destruction of, objects." 58

"A device, system, munition, implement, substance, object, or piece of equipment that is used, that is intended to use, or that has been designed for the use to apply offensive capability, usually causing injury or damage to an adverse party to an armed conflict" may also constitute a weapon. ${ }^{59}$ Thus, a weapon will be capable of causing harm in the form of injury, suffering or death to humans; or damage or destruction to objects.

"Means" is defined by Rule 1(t) of the HPCR Manual as "weapons, weapon systems or platforms

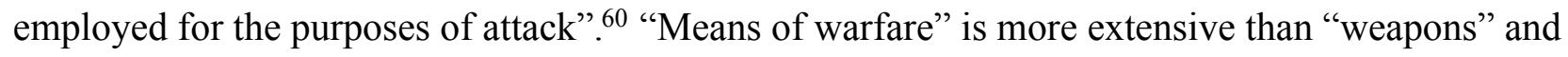
includes platforms and equipment (e.g. a ground based target designator used to guide a weapon to its target qualifies as a component part of a means of warfare) which make an attack possible. Thus, a UCAV, which is an unmanned military aircraft that carries and launches a weapon or which can use on-board technology to direct such a weapon to a target, constitutes a "means of warfare". ${ }^{61}$

"Methods" is defined under Rule 1(v) as:

“attacks and other activities designed to adversely affect the enemy's military operations or military capacity, as distinct from the means of warfare used during military operations, such as weapons. In military terms, methods of warfare consist of the various general categories of operations, such as bombing, as well as the specific tactics used for attack, such as high altitude bombing." 62

\footnotetext{
58 HPCR Manual (2013), The Program on Humanitarian Policy and Conflict Research at Harvard University, HPCR Manual on International Law Applicable to Air and Missile Warfare (2013), p. xxv.

59 William H. Boothby, Weapons and the Law of Armed Conflict (OUP 2016) p. 4.

${ }^{60}$ HPCR Manual (2013), supra note 58, p. xxiv. Boothby, id., p. 5 (has a similar formulation but includes "associated equipment used directly to deliver force during hostilities").

${ }^{61}$ HPCR Manual (2013), supra note 58, Commentary to Rule 1(t), p. 31.

${ }^{62}$ HPCR Manual (2013), supra note 58, p. xxiv; Boothby, supra note 59, p. 5.
} 
LAWS, for example, would constitute a "new" weapon or means of warfare due to their key features of autonomy and removal of human involvement. They are a type of weapon designed or intended to be used with offensive capability. They are weapons systems employed for attack and, therefore, also constitute a means of warfare. Controversially, some states exclude "platforms" from weapons reviews because they do not consider them "weapons". ${ }^{3}$ The USA, not a state party to API but recognising a customary international law duty to conduct weapons reviews, refers to UCAV as "platforms" and, for the purposes of conducting weapons reviews, their definition of weapons and weapons systems excludes "platforms". ${ }^{64}$ The 2011 UK Joint Doctrine Note refers to "currently fielded or in-development unmanned aircraft" as "platforms", which do not fall under their definition of an autonomous system and would not be subject to a weapons review. ${ }^{65}$ However, several states regard UCAV as semi-autonomous weapons subject to weapons review and falling within the mandate of the GGE. ${ }^{66}$ This highlights problems around implementation of the review obligation.

Without any international monitoring or oversight, states have discretion to designate weapons, means, or methods for the purposes of Article 36 reviews and, therefore, not all new technologies may be assessed for compliance with IHL. Article 36 reviews do not solve the underlying issue of whether new technologies should be introduced in warfare. The review procedure is non-transparent and non-reciprocal so that regulation of new weapons under Article 36 is effectively a selfregulation model. States are not obliged to share review assessments, and are not bound by each other's assessments.

\section{Conclusion}

Despite new weapons technologies impacting on warfare, IHL continues to apply and reaffirm the central role of human agency. IHL can be strengthening in terms of effective application and implementation in several ways. The lawfulness of any new weapons systems should be measured

\footnotetext{
${ }^{63}$ See for example, Dutch-Swiss paper (2017), Weapons Review Mechanisms, CCW/GGE.1/2017/WP.5, para. 28.

64 Review of Legality of Weapons under International Law, US Department of Defense, Army Regulation 27-53, 1 January 1979; Legal Reviews of Weapons and Cyber Capabilities, US AIR FORCE INSTRUCTION 51-402, 27 JULY 2011.

65 UK Ministry of Defence Joint Doctrine Note 2/11 (2011), The UK Approach to Unmanned Aircraft Systems (30 March 2011), para. 206.

66 Ozlem Ulgen, “World Community Interest' approach to interim measures on 'robot weapons': revisiting the Nuclear Test Cases' (2016) 14 New Zealand Yearbook of International Law pp. 3-34.
} 
against existing IHL rules as contained in Articles 1(2), 35(2), 36, 48, 51, 51(4)(b) and (c), 51(5)(b), 57(1), 57(2)(a)(ii) and (iii), 57(2)(b), 58 API. Moreover, it is both the nature and use of the weapons systems which will need to be considered. Implementation of IHL principles is clearly directed at human agents and illustrates how and why human involvement is necessary in the context of use and employment of new weapons. Human involvement should be understood as the human agency continuum whereby actual and effective human judgment and reasoning is exercised throughout the pre-deployment and deployment stages of a weapon's lifecycle.

Strengthening Article 36 weapons review in relation to new weapons technologies will more than likely require some form of international monitoring or oversight. Ongoing reviews are essential to ensure proper performance and functionality that is IHL compliant, taking account of modifications and additions made to new technology, and performance issues of "dynamic learning systems". Different stages in the weapon's lifecycle would need to be subjected to rigorous reviews and involve several different human agents (e.g. designers, programmers, engineers, manufacturers, private contractors, private military firms). ${ }^{67}$ This also relates to an expanded notion of command responsibility so that subordinates go beyond combatants to include designers, engineers, programmers, and manufacturers tasked with creating and maintaining a new weapons system.

${ }^{67}$ Ulgen, supra note 18. 